\title{
Production and quality of milk from Mantiqueira dairy cows feeding on Mombasa grass pasture and receiving different sources of roughage supplementation ${ }^{1}$
}

\author{
Afonso Aurélio de Carvalho Peres ${ }^{2,3}$, Carlos Augusto Brandão de Carvalho ${ }^{3}$, Maria Inês de \\ Aquino Barbosa Carvalho ${ }^{3}$, Hernán Maldonado Vasquez ${ }^{4,5}$, José Fernando Coelho da \\ Silva ${ }^{4,5}$, Renata Cogo Clipes $^{4}$, Mirton José Frota Morenz ${ }^{4}$
}

\footnotetext{
${ }^{1}$ Financial support received from APTA, FAPERJ and CAPES.

2 Departamento de Engenharia de Agronegócios, Universidade Federal Fluminense (UFF), Volta Redonda, RJ, Brazil.

${ }_{3}^{3}$ Pólo Regional Vale do Paraíba, Agência Paulista de Tecnologia dos Agronegócios (APTA), Pindamonhangaba, SP, Brazil.

${ }^{4}$ Centro de Ciências e Tecnologias Agropecuárias, Universidade Estadual do Norte Fluminense (UENF), Campos dos Goytacazes, RJ, Brazil.

${ }^{5}$ Research Assistant of National Research Council (CNPq), Brazil.
}

\begin{abstract}
Production and quality of milk from dairy cows grazing exclusively on Mombasa grass pasture, during the spring-summer period and fed roughage supplementations, during the autumn-winter, were evaluated in two consecutive years. The pasture of 11.4 ha was divided into 57 paddocks of 2,000 $\mathrm{m}^{2}$ each, including three replications with 19 paddocks each. The pasture was managed with two occupation days and 36 resting days. During the spring-summer period, cows received only grass pasture. In the autumn-winter period, they had access to Mombasa grass pasture and received roughage supplementations (black oat pasture; sorghum silage or sugarcane + urea) and pasture every 28 days, alternately. The animals had access to mineral mix and water and received $500 \mathrm{~g}$ of concentrated in each of the two milking times. The experimental design used was for response to continuous flow in rotational trial, similar to the Latin square model. In the spring-summer period, the average milk production was $12.2 \pm 2.2$ and $14.0 \pm 3.8 \mathrm{~kg} / \mathrm{cow}$ per day; for the autumn-winter period, the milk production was $13.5 \pm 2.9$ and $12.1 \pm 2.5 \mathrm{~kg} / \mathrm{cow}$ per day in the black oat pasture; $11.8 \pm 2.5$ and $10.9 \pm 2.3 \mathrm{~kg} / \mathrm{cow}$ per day in the sorghum silage and $11.3 \pm 1.8$ and $8.4 \pm 1.5 \mathrm{~kg} / \mathrm{cow}$ per day in the sugarcane + urea, for $1^{\text {st }}$ and $2^{\text {nd }}$ years evaluated, respectively. The black oat was the roughage supplementation that yielded the highest average daily milk production. There were no differences in the milk chemical composition between roughage supplementations.
\end{abstract}

Key Words: black oat, dairy cattle, rotational stocking, sorghum silage, sugarcane

\section{Introduction}

Production systems based on pasture as main source of nutrients must use a roughage supplementation during the year, whether naturally occurring or conserved, with focus on cost reduction and decrease in the use of concentrates, for higher production efficiency and competitively of the systems.

The inefficiency and unprofessionalism of some production systems can be seen in some regions of Brazil, because of the diversity of management and technology applied, resulting in low production index and high production cost.

Census done in the region of Vale do Rio Paraíba do Sul, State of São Paulo, Brazil showed that $41.52 \%$ of livestock systems is based on cattle production (São Paulo, 2008), including $19.81 \%$ that represents mixed dairy and beef animals, $12.03 \%$ of dairy production and $9.68 \%$ meat production. Most rural properties have no records about the productive and economic efficiency of the systems.

Milk production systems based on pasture constitute the most economical way to produce. However, during the spring and summer, Holstein-Zebu cows can produce, on average, 11.6 and $12.4 \mathrm{~kg}$ of milk per day without supplementation, or receiving $2 \mathrm{~kg}$ of concentrate per day, respectively (Deresz, 2001b), which is not observed during autumn-winter, when it is necessary to use supplements. Mombasa grass pasture managed at a height lower than $100 \mathrm{~cm}$ allows Holstein cows to produce on average $14.0 \mathrm{~kg}$ milk per day (Hack et al., 2007). According to these authors, Mombasa grass pasture managed up to $100 \mathrm{~cm}$ of height allows Holstein cows to produce on average $14.0 \mathrm{~kg}$ milk per day.

Animals adapted to the tropics and fed exclusively on pasture during the spring and summer can produce between 12 and $14 \mathrm{~kg}$ of milk per day (Alvim et al., 1997). The formation of Mantiqueira cattle began in 1952, from the 
selection of animals from herds in southern of the state of Minas Gerais, Brazil. The crossbred animals Creole-Caracu were crossed with Holstein animals, giving rise to Mantiqueira cattle. These animals are characterized by their medium size, good milk production and fertility, and adaptation to rustic systems, demonstrating high capacity of transmission of the ideal characteristics for milk production on pasture to their offspring (São Paulo, 1984).

The objective of this research was to evaluate the production and quality of the milk produced by Mantiqueira cows managed on Mombasa grass pasture, supplemented with or without roughage.

\section{Material and Methods}

The experiment was carried out at the Polo Regional do Vale do Paraíba, belonging to Agência Paulista de Tecnologia dos Agronegócios (APTA), located in Pindamonhangaba, São Paulo, Brazil, from October 2004 to August 2006, during the periods of spring-summer (rainy season) and autumnwinter (dry season). The Pole is located in the São Paulo region of Rio Paraíba on the Tropic of Capricorn; the city is situated at geographical coordinates $22^{\circ} 32^{\prime} \mathrm{S}$ and $45^{\circ} 16^{\prime} \mathrm{W}$, and $540 \mathrm{~m}$ of altitude. The climate, according to the Köppen classification, is mesothermal Cwa with hot and rainy summer and dry winter (UNICAMP, 2011). Average temperature of the coldest month is around $18{ }^{\circ} \mathrm{C}$ and the warmest month above $22^{\circ} \mathrm{C}$ with relative humidity average of $92.8 \%$. During the dry season, rainfall does not exceed $30 \mathrm{~mm}$ and the annual rainfall distribution varies between 1,100 to $1,700 \mathrm{~mm}$ in the lower areas of the region (São Paulo, 1999). The autumn-winter period (dry season) extends from April to September with maximum intensity in July and the springsummer period (rainy season) from October to March, with peak rainfall occurring in January. The land relief of the region varies from flat to undulating with good drainage; with soils originated from sandy-clayey sediments and Tertiary Quaternary alluvium with good drainage (Verdade et al., 1961).

The experimental area was constituted by 11.4 hectares of Mombasa grass pasture (Panicum maximum, Jacq., cv. Mombasa), formed in February of 2004, initially receiving liming to increase the soil base saturation to $60 \%$, and fertilization according to technical Bulletin IAC 100 (Raij et al., 1996). Five hundred kilograms/hectare of NPK fertilizer (20:05:20) were applied in two fractions, during the spring and summer.

The area was divided into 57 paddocks of 2,000 $\mathrm{m}^{2}$, distributed in three replications with 19 paddocks each. The paddocks were managed with two days of occupation and defoliation interval of 36 days during spring and summer, and one day of occupation and 56 days of defoliation interval in autumn and winter.

Sixty Mantiqueira cows were selected in a herd of, approximately, 450 animals. The selected animals were submitted to estrus synchronization protocol, and 36 cows ( $511 \pm 44 \mathrm{~kg}$ body weight) were evaluated in spring-summer period (12 cows per replicate) and 24 cows $(502 \pm 38 \mathrm{~kg}$ of body weight) in autumn-winter period (eight per roughage supplementation). The animals were distributed according to their racial group, the order of parity (between $3^{\text {rd }}$ and $5^{\text {th }}$ parturition), body weight, stage of lactation and milk production, for the formation of homogeneous groups between the supplements evaluated. The mean yields between 8 and $12 \mathrm{~kg}$ of milk/cow/day, as well as the similarity of physiological state of the animals were used to form the groups, according to the methodology proposed by Pimentel Gomes (2000). Experimental animals showed physiological state between 40 and 60 days after calving, as suggested by Sampaio (2002). The results were analyzed considering the milk yields obtained from the $40^{\text {th }}$ to the $150^{\text {th }}$ day of lactation.

During the spring and summer the animals grazing Mombasa grass pasture received $500 \mathrm{~g}$ of concentrate containing $210 \mathrm{~g}$ of crude protein and $380 \mathrm{~g}$ of neutral detergent fiber per kg of dry matter, in each milking, at 6:00 and 15:00 hours. In the fall and winter, in addition to this diet, the animals also received roughage supplementation, between the milking, with access to Mombasa pasture in rest of the day, when they had unrestricted access to mineral supplement, water and shaded rest areas.

The sources of roughage supplementation evaluated during the autumn-winter period were: black oat, cv. Embrapa 29 pasture, managed under grazing in range daily, with available area of $100 \mathrm{~m}^{2} /$ animal; sugarcane, cv. IAC 862480 , chopped and with inclusion of $10 \mathrm{~g}$ of urea/100 kg body weight, supplied in the amount of $35 \mathrm{~kg} / \mathrm{cow} /$ day; and sorghum silage, cv. Volumax ${ }^{\circledR}$, provided in the amount of $30 \mathrm{~kg} / \mathrm{cow} /$ day. The areas used for roughage supplements production were 4.5, 0.5 and 1.0 hectares for the black oat, sugarcane and sorghum silage, respectively. At every 28 days, rotation of roughage supplements was done.

The samples used to evaluate the nutritional value of pastures (Mombasa grass and oats) were obtained by hand-plucked method, on the first day of each paddock occupation. Roughage supplement (sugarcane and sorghum silage) samples were collected before the animal feeding. The forage mass of pasture was determined using a square $(1.0 \times 1.0 \mathrm{~m})$, thrown over three points of the paddock area. The forage contained within the square was cut to $10 \mathrm{~cm}$ 
height and collected for posterior determination of herbage mass per unit area ( $\mathrm{kg} / \mathrm{ha}$ of dry matter).

The sward height inside of the square was obtained in five different points, using a graduated ruler, every $5 \mathrm{~cm}$. Before the entry of animals in the paddocks, the sward height was measured in 50 different points. The same methodology was used to determine the sward height and herbage mass residual in post-grazing. Forage intake in pasture was estimated according to Deresz (2001a), determined based on the forage removed ( $\mathrm{kg} / \mathrm{ha}$ of dry matter). This estimative was made by grazing cycles and divided by the number of paddocks, and the result was divided by the average stocking rate of pasture (animals/ha), and this value was then divided by the number of occupation days of the paddocks. Loss of forage in the pasture was also considered, corresponding to $30 \%$. The intake estimative of the roughage supplement provided was obtained by the difference between the quantity supplied and the orts.

The milk production was measured three times a week, and used for estimation of production during the experimental period. The results obtained in the springsummer period were analyzed using descriptive statistics using means and standard deviations, and in the autumnwinter period, they were evaluated in accordance with the experimental design for continuous flow response in rotational trials, proposed by Sampaio (2002).

The milk quality was evaluated using composite samples constituted by samples collected from four mammary quarters, from each cow, every seven days in morning milking, after weighing the milk, using the equipment Mark V ${ }^{\circledR}$ (Delaval Ltda). The samples were placed in plastic recipients $\left(25.0 \mathrm{~mL}\right.$ ) containing preservative (bronopol ${ }^{\circledR}$ ), without refrigeration, and sent to the Laboratory of Clinical Analyses Milk, ESALQ-USP. The somatic cell count (SCC) was determined by flow cytometry in equipment flowmeter Somacount $500{ }^{\circledR}$ (Bentley Instruments Inc.), from the total reading of electronic counting of somatic cells in 1000 cells $/ \mathrm{mL}$. The levels of protein, fat and lactose were determined in $\mathrm{g} / \mathrm{kg}$ of milk by infrared absorption spectrophotometry, in equipment Bentley 2000 ${ }^{\circledR}$ (Bentley Instruments Inc.).
The data were submitted to analysis of variance and means were compared by Tukey test at 0.05 of probability, using SAEG software (Sistema para Análises Estatísticas, version 9.0).

\section{Results and Discussion}

The average sward height of the Mombasa grass pasture in spring-summer period, at pre-grazing, was $90 \pm 25 \mathrm{~cm}$, and the average forage mass was $5,971 \pm 1,557 \mathrm{~kg} / \mathrm{ha}$ of DM (Table 1 ). The sward height in the post grazing was $41 \pm 12 \mathrm{~cm}$. The values of forage mass obtained are between the minimum and maximum values reported by Silva et al. (2009) for Mombasa grass pasture managed with $30 \mathrm{~cm}$ of residue post-grazing, under rotational grazing (4,940 and 6,800 kg/ha of DM). According to these authors, the management of sward height recommended in pre-grazing and post-grazing during the spring-summer period is $90 \mathrm{~cm}$ and $30 \mathrm{~cm}$, respectively. This management allows higher efficiency production of pasture, with better nutritional value, reflecting in the increase in animal production. This fact can be verified, considering that the milk production observed in Mantiqueira cows was between 12.2 and $14.0 \mathrm{~kg} /$ cow/day during the spring-summer period, confirming the Deresz (2001b) assertion, that in grazing systems it is possible to obtain average milkproduction of $11.6 \mathrm{~kg} / \mathrm{cow} /$ day, or $12.4 \mathrm{~kg} / \mathrm{cow} /$ day with the supply of $2 \mathrm{~kg} / \mathrm{cow} /$ day of concentrate, during the rainy season.

During the autumn-winter period, the average values for sward height and forage mass of Mombasa grass pasture in pre-grazing was $58 \pm 21 \mathrm{~cm}$ and $4,433 \pm 1,339 \mathrm{~kg} / \mathrm{ha}$ of DM (Table 1), respectively, with a residue height of $34 \pm 11 \mathrm{~cm}$. The forage mass value obtained in this period was smaller than that reported by Silva et al. (2009) for Mombasa grass pasture managed with $30 \mathrm{~cm}$ of residue height $(5,150 \mathrm{~kg} / \mathrm{ha}$ of DM). The lower forage mass observed may be a result of grazing management at the end of spring-summer period, when the sward presented the greater height in the post-grazing, resulting in the extension of the stems.

Table 1 - Forage mass and nutritive value of roughage supplied to experimental animals ${ }^{1}$

\begin{tabular}{|c|c|c|c|c|c|}
\hline Item & Mombasa grass $^{2}$ & Mombasa grass 3 & Black oat & Sorghum silage & Sugarcane \\
\hline Forage mass (kg/ha of DM) & $5,971 \pm 1,557$ & $3,615 \pm 712$ & $3,019 \pm 887$ & - & - \\
\hline Dry matter (g/kg of DM) & $246.7 \pm 26.4$ & $253.8 \pm 18.3$ & $228.1 \pm 26.4$ & $313.4 \pm 15.3$ & $232.3 \pm 24.1$ \\
\hline Crude protein (g/kg of DM) & $99.1 \pm 24.3$ & $102.2 \pm 14.5$ & $223.8 \pm 10.2$ & $71.9 \pm 12.4$ & $49.1 \pm 8.7$ \\
\hline Neutral detergent fiber (g/kg of DM) & $707.3 \pm 30.7$ & $649.6 \pm 47.6$ & $466.1 \pm 25.7$ & $643.1 \pm 66.8$ & $535.3 \pm 65.3$ \\
\hline Acid detergent fiber (g/kg of DM) & $386.6 \pm 31.3$ & $384.4 \pm 26.2$ & $285.0 \pm 1.6$ & $403.9 \pm 46.1$ & $321.8 \pm 32.5$ \\
\hline Dry matter in vitro digestibility (g/g) & $0.652 \pm 0.39$ & $0.616 \pm 0.61$ & $0.767 \pm 0.36$ & $0.629 \pm 0.49$ & $0.654 \pm 0.32$ \\
\hline
\end{tabular}

${ }^{1}$ Mean and standart deviation.

2 Samples collected in spring-summer period.

3 Samples collected in autumn-winter period.

DM - dry matter. 
The forage mass of oat forage available was $3,019 \pm 887 \mathrm{~kg} / \mathrm{ha}$ of DM and the average sward height was $83 \pm 18 \mathrm{~cm}$. The oat forage mass observed was lower than that found by Aguinaga et al. (2008) in oats and ryegrass pasture, in which they obtained production of 7,702 kg/ha of DM, in a sward height in the pre-grazing of $67 \mathrm{~cm}$. The lower yield obtained for oats can be explained by different soil and climatic conditions between the regions of study, since the conditions of precipitation and temperature were more favorable to the forage growth in the study published by Aguinaga et al. (2008).

The values of chemical composition and in vitro dry matter digestibility obtained for Mombasa forage grass pasture in both evaluation periods (Table 1 ) were satisfactory and are according to results published by Valadares Filho et al. (2006). The lower values observed for crude protein content in Mombasa grass during spring-summer can be attributed to increase in plants growth, thus promoting a decrease in nitrogen concentrations due to dilution effect (Botrel et al., 2000). However, due to the low values of forage mass and digestibility of the Mombasa grass, which compromised the nutritional value of the diet consumed by grazing cows, the use of roughage supplementation with oats pasture was sufficient to complement the nutrients supply to meet the nutritional requirements of the animals. The forage of oats pasture is characterized by having a low content of neutral detergent fiber, high protein content, associated with good values of dry matter digestibility, which resulted in higher milk production when compared with other sources of roughage supplementation (Table 2).

However, there were observed limitations concerning forage quality of sorghum silage, which presented high levels of neutral detergent fiber and low digestibility of dry matter. Sugarcane presents as the main limitation the low crude protein content, resulting in daily milk yields lower than those obtained when cows were supplemented with black oat pasture. The result of dry matter digestibility $(0.654 \pm 0.32 \mathrm{~g} / \mathrm{g})$ obtained for sugarcane is similar to those observed by Landell et al. (2002), who found levels ranging between 0.632 and $0.659 \mathrm{~g} / \mathrm{g}$, during the autumn-winter. The results obtained for chemical composition and digestibility of dry matter of the roughage supplements (sorghum silage and sugarcane) are similar to those published by Valadares Filho et al. (2006).

The average stocking rate obtained in spring-summer period in Mombasa grass pasture was 3.24 and 3.16 AU/ha, in the years 2004-2005 and 2005-2006, respectively. The low stocking rate described can be explained by maintenance fertilization performed annually (500 kg of NPK fertilizer 20-05-20).
Porto et al. (2009) evaluated Holstein $\times$ Zebu cows, managed in Tanzania grass pasture, during summer-autumn period, and obtained average daily milk production of $9.8 \mathrm{~kg}$ per cow, supplying $2 \mathrm{~kg} / \mathrm{cow} /$ day of concentrate. This production level is lower than those observed in the present study, and can be related to the stocking rate obtained by the authors, which was 4.0 cows/ha, against 3.1 and 3.4 cows/ha observed in both years of evaluation in the present research, and also to the ecotype of the animals.

The average daily milk production was influenced $(\mathrm{P}<0.05)$ by supplementation, with higher values observed when black oat pasture was used as a supplement in both years of evaluation (Table 2). The higher values of individual milk production of cows that had access to black oat pasture is related, mainly, to dry matter intake (Table 2) and the quality of forage consumed (Table 1), given the best nutritional value of black oat pasture, compared with sorghum silage and sugarcane. Milk production of cows grazing black oat pasture was higher than that observed by Souza et al. (1990), who reported mean values of $11.6 \mathrm{~kg} /$ cow/day, with a stocking rate of 2.0 cows/ha. The dry matter intake estimated of forage in Mombasa grass pasture during the autumn-winter period was $3.0 \mathrm{~kg} / \mathrm{cow} / \mathrm{day}$, and it was not the main source of roughage consumed by dairy cows, representing only $7 \mathrm{~g} / \mathrm{kg}$ of body weight.

Considering the available area of grassland, the area used for production of the roughage supplements and the concentrate supplied daily (1.0 kg/cow/day), low stocking rate for the milk production systems evaluated was observed (Table 2).

The average daily milk production ( $8.9 \mathrm{~kg} / \mathrm{cow} /$ day) in the system that used sugarcane supplementation was higher than that obtained by Landell et al. (2002), who assessed the potential of elephant grass pasture supplemented with sugarcane and $2.0 \mathrm{~kg} / \mathrm{cow} /$ day of concentrate. The lower

Table 2 - Milk production, estimated dry matter intake and stocking rate in Mombasa grass pasture supplemented in the autumn-winter period

\begin{tabular}{cccc}
\hline Year & Black oat ${ }^{1}$ & Sorghum silage $^{1}$ & Sugarcane $^{1}$ \\
\hline \multirow{3}{*}{2005} & $13.5 \pm 2.9 \mathrm{a}$ & Milk production (kg/cow/day) \\
2006 & $12.1 \pm 2.5 \mathrm{a}$ & $10.9 \pm 2.5 \mathrm{~b}$ & $11.3 \pm 1.8 \mathrm{~b}$ \\
& Intake estimated in $\mathrm{kg} /$ cow/day (g/kg of body & $8.4 \pm 1.5 \mathrm{c}$ \\
2005 & $10.9(24)$ & $7.0(15)$ & $7.8(17)$ \\
2006 & $10.5(23)$ & $6.8(14)$ & $7.2(15)$ \\
& & & \\
2005 & 0.96 & Stocking rate (AU/ha) \\
2006 & 1.21 & 1.67 & 1.86 \\
\hline
\end{tabular}

${ }^{1}$ Mean and standart deviation. Means followed by same letters, in rows, are not significantly different $(\mathrm{P}>0.05)$. 
milk production obtained with this source of forage corroborates the assertion of other authors (Magalhães et al., 2004; Souza et al., 2009), that dairy cows fed with sugarcane produce less than when fed with corn silage. Similar trend was observed with Mantiqueira cows producing between 15 and 30\% less when supplemented with black oat and between 5 and 23\% less when supplemented with sorghum silage.

The average levels of fat, protein, lactose and total solids in milk were not influenced $(\mathrm{P}>0.05)$ by roughage supplements during the autumn-winter period (Table 3 ).

The average fat content $(32.0 \mathrm{~g} / \mathrm{kg}$ of milk) obtained in the spring-summer period was lower than that reported by Porto et al. (2009), who evaluated Holstein $\times$ Zebu grazing cows on Tanzania grass pasture supplemented with $2 \mathrm{~kg} / \mathrm{cow} /$ day of concentrate ( $38.0 \mathrm{~g} / \mathrm{kg}$ of milk). However, it is noteworthy that the fat content in milk is more related to genetic factors than to the diet.

During the spring-summer period, there was higher fat content in milk ( $32.0 \mathrm{~g} / \mathrm{kg}$ of milk), probably due to the increase in forage available and unrestricted access to pasture, which was the main source of nutrients and, considering that Mombasa grass pasture constituted the higher proportion of the diet in this period, an increase in the acetic acid production, which is the major precursor for milk fat synthesis, may have occurred.

According to Lucci (1997), the nitrogen composition of the diet can influence the milk fat content, so that increases in dietary protein concentration of 120 to $180 \mathrm{~g} / \mathrm{kg} \mathrm{DM}$ reduce the concentration of fat in up to $5 \mathrm{~g} / \mathrm{kg}$ of milk, due to the increase in milk production, while small additions in protein contents with increase in dietary protein levels occur, which was not observed in this study. Bachman (1992) reported there is need for increases of nearly $100 \%$ in crude protein content in the diet, and the daily dry matter intake requirements need to be met in order to obtain an increase in the milk protein content.

The low average values for milk protein content obtained in the autumn-winter period (Table 3) did not corroborate with those predicted by Standard Rules n ${ }^{\circ} 51$
(IN. 51), of September 18, 2002, determined by Ministério da Agricultura, Agropecuária e Abastecimento (MAPA), which establishes criteria for the improvement and modernization of Federal Health Legislation related to milk production (Brasil, 2002), considering that the IN. 51 states that, to classify the milk as "type C cooled raw milk", the milk must present minimal protein content values of $29.0 \mathrm{~g} / \mathrm{kg}$.

It is noteworthy that the low values obtained for milk protein content may be attributed to diet or method of milk sample collection.

Considering the nutritional aspect, some references report the energy content of the diet is one of the main factors that influence the milk protein content (Schingoethe et al., 1996; Pulina et al., 2006). When the energy content of the diet increases, due to inclusion of concentrate foods, the addition of rapidly fermentable non-fibrous carbohydrate (NFC), results in higher propionate production in the rumen, which reduces the amino acids use for gluconeogenesis, allowing its use for the milk protein synthesis (Susin et al., 1995). In addition, the synchronization between the degradation of nitrogen compounds and carbohydrates in the rumen is also an important point (Schingoethe et al., 1996), which increases the efficiency of microbial protein synthesis and thus, allows higher availability of amino acids for the milk protein synthesis.

Concerning the procedure for milk collection, given that the samples were taken every seven days during the morning milking - as described in the methodology -, it is noteworthy that the most appropriate methodology is to obtain a composite sample constituted of $2 / 3$ of the milk coming from the morning milking and $1 / 3$ of the milk collected in the afternoon milking, in order to obtain a more representative sample. In this context, the collection of samples only during morning milking can lead to underestimated values of the milk components, considering the higher milk production in this period. Likewise, the collection of samples in the afternoon milking can result in overestimated values due to lower production and, consequently, higher concentration of these components.

Table 3 - Mean and standard deviation for the milk composition, according to roughage supplementation, in the spring-summer and autumn-winter periods

\begin{tabular}{lcrrr}
\hline Components $(\mathrm{g} / \mathrm{kg}$ milk) & Spring-summer & \multicolumn{2}{c}{ Autumn-winter } \\
\cline { 2 - 4 } \cline { 4 - 5 } & Mombasa grass & Black oat & Sugarcane & $30.9 \pm 6.8$ \\
Fat & $32.0 \pm 9.7$ & $29.1 \pm 5.4$ & $27.4 \pm 2.2$ & $30.0 \pm 6.2$ \\
Protein & $29.1 \pm 2.5$ & $27.8 \pm 3.6$ & $43.6 \pm 3.2$ & $44.3 \pm 2.7$ \\
Lactose & $43.4 \pm 2.5$ & $43.1 \pm 4.6$ & $111.2 \pm 8.4$ & $110.5 \pm 9.9$ \\
Total solids & $114.7 \pm 10.5$ & $109.4 \pm 5.9$ & \\
\hline
\end{tabular}




\section{Conclusions}

Mombasa grass pasture managed under rotational stocking during the spring-summer period allows daily milk productions ( $\mathrm{kg} /$ day) close to that obtained in the autumnwinter period with the use of black oat pasture, sorghum silage or sugarcane as roughage supplement. The use of black oat pasture as a roughage supplementation during the autumn-winter period presented as the best option to promote higher daily milk productions, due to their chemical composition and digestibility. The use of roughage supplementation during the autumn-winter period, associated with the low supply of concentrate does not promote increase on fat, protein, lactose or total solids of milk from Mantiqueira grazing cows managed in Mombasa grass pasture.

\section{Acknowledgements}

The authors thank the companies Sociedade Extrativa Dolomia Ltda, Comércio e Indústria Importação e Exportação Matsuda Ltda, Delaval Ltda e Alta Genética Ltda, for the supply of inputs, the assistance with the field experiment, and the sponsorship for the farmers meeting events organized by Polo Regional do Vale do Paraíba, in Pindamonhangaba, SP.

\section{References}

AgUinAGA, A.A.Q.; CARVALHO, P.C.F.; ANGHINONI, I. Componentes morfológicos e produção de forragem de pastagem de aveia e azevém manejada em diferentes alturas. Revista Brasileira de Zootecnia, v.37, n.9, p.1523-1530, 2008.

ALVIM, M.J.; VILELA, D.; LOPES, R.S. Efeito de dois níveis de concentrado sobre a producao de leite de vacas da raça Holandesa em pastagem de Coast-cross (Cynodon dactilon, L., Pers). Revista Brasileira de Zootecnia, v.26, n.5, p.967-975, 1997.

BACHMAN, K.C. Managed milk composition. In: VAN HORN, H.H.; WILCOX, C.J. (Eds.) Large dairy herd management. Champaign: American Dairy Science Association, 1992. p.336-346.

BOTREL, M.A.; PEREIRA, A.V.; FREITAS, V.P. et al. Potencial forrageiro de novos clones de capim-elefante. Revista Brasileira de Zootecnia, v.29, n.2, p.334-340, 2000.

BRASIL. Ministério da Agricultura, Pecuária e Abastecimento (MAPA). Gabinete do Ministro. Instrução normativa n.51, de 18 de setembro de 2002. Aprova os regulamentos técnicos de produção, identidade e qualidade do leite tipo A, do leite tipo B, do leite tipo C, do leite pasteurizado e do leite cru refrigerado e o regulamento técnico da coleta de leite cru refrigerado e seu transporte a granel. Diário Oficial da República Federativa do Brasil, Brasília, DF, 18 de setembro de 2002. 55p.

DERESZ, F. Influência do período de descanso da pastagem de capim-elefante na produção de leite de vacas mestiças holandês x zebu. Revista Brasileira de Zootecnia, v.30, n.2, p.461-469, 2001a.

DERESZ, F. Produção de leite de vacas mestiças Holandês x Zebu em pastagem de capim-elefante, manejada em sistema rotativo com e sem suplementação durante a época das chuvas. Revista Brasileira de Zootecnia, v.30, n.1, p.197-204, 2001b.

HACK, E.C.; BONA FILHO, A.; MORAES. A. et al. Características estruturais e produção de leite em pastos de capim-Mombaça (Panicum maximum Jacq.) submetidos a diferentes alturas de pastejo. Revista Ciência Rural, v.37, n.1, p.218-222, 2007.

LANDELL, M.G.A.; CAMPANA, M.P.; RODRIGUES, A.A. et al. A variedade IAC86-2480 como nova opção de cana-de-açúcar para fins forrageiros: manejo de produção e uso na alimentação animal. Campinas: Instituto Agronômico de Campinas, 2002. 36p. (Boletim Técnico, 193).

LUCCI, C.S. Nutrição e manejo de bovinos leiteiros. São Paulo: Editora Manole, 1997. 169p.

MAGALHÃES, A.L.R.; CAMPOS, J.M.S.; VALADARES FILHO, S.C. et al. Cana-de-açúcar em substituição à silagem de milho em dietas para vacas em lactação: desempenho e viabilidade econômica. Revista Brasileira de Zootecnia, v.33, n.5, p.1292-1302, 2004.

PIMENTEL-GOMES, F. Curso de estatística experimental. 14.ed. Piracicaba: Gráfica e Editora Degaspari, 2000. 477p.

PORTO, P.P.; DERESZ, F.; SANTOS, G.T. et al. Produção e composição química do leite, consumo e digestibilidade de forragens tropicais manejadas em sistema de lotação intermitente. Revista Brasileira de Zootecnia, v.38, n.8, p.1422-1431, 2009.

PULINA, G.; NUDDA, A.; BATTACONE, G. et al. Effects of nutrition on the contents of fat, protein, somatic cells, aromatic compounds, and undesirable substances in sheep milk. Animal Feed Science and Technology, v.131, n.3-4, p.255-291, 2006.

RAIJ, V.B.; CANTARELLA, H.; QUAGGIO, J.A. et al. Recomendações de adubação e calagem para o Estado de São Paulo. 2.ed. Campinas: Instituto Agronômico de Campinas, 1996. 285p. (Boletim técnico, 100).

SAMPAIO, I.B.M. Estatística aplicada à experimentação animal. 2.ed. Belo Horizonte: Fundação de Ensino e Pesquisa em Medicina Veterinária e Zootecnia, 2002. 265p.

SÃO PAULO. Secretaria de Agricultura e Abastecimento. Coordenadoria da Pesquisa Agropecuária. Instituto de Zootecnia. Mantiqueira - 30 anos depois. São Paulo: SAA/CPA/IZ, 1984. 31p.

SÃO PAULO. Secretaria de Agricultura e Abastecimento. Coordenadoria de Assistência Técnica Integral. Instituto de Economia Agrícola. Levantamento censitário de unidades de produção agrícola do Estado de São Paulo - lupa 2007/ 2008. São Paulo: SAA/CATI/IEA, 2008. Available at: <http:// www.cati.sp.gov.br/projetolupa>. Accessed on: Mar. 28, 2011.

SÃO PAULO. Secretaria de Recursos Hídricos, Saneamento e Obras. Projeto qualidade das águas e controle da poluição hídrica na bacia do Rio Paraíba do Sul. São Paulo: SRHSO, 1999. (CD-ROM).

SCHINGOETHE, D.J. Dietary influence on protein level in milk and milk yield in dairy cows. Animal Feed Science and Technology, v.60, n.3-4, p.181-190, 1996.

SILVA, S.C.; BUENO, A.A.O.; CARNEVALLI, R.A. et al. Sward structural characteristics and herbage accumulation of Panicum maximum cv. Mombaça subjected to rotational stocking managements. Scientia Agricola, v.66, n.1, p.8-19, 2009.

SOUZA, D.P.; CAMPOS, J.M.S.; VALADARES FILHO, S.C. et al. Comportamento ingestivo, consumo e digestibilidade de nutrientes, produção e composição do leite de vacas alimentadas com silagem de milho ou cana-de-açúcar com caroço de algodão. Revista Brasileira de Zootecnia, v.38, n.10, p.2053-2062, 2009.

SOUZA, J.M.; CARDOSO, S.; OLÍVIO, C. et al. Desempenho de vacas leiteiras com pastagem de aveia e silagem de milho Ijuí: Cooperativa Regional Tritícola Serrana Ltda, 1990. p.4. (Comunicado Técnico, 24).

SUSIN, I.; LOERCH, S.C.; McCLURE, K.E. Effects of feeding a high-grain diet at a restricted intake on lactation performance 
and rebreeding of ewes. Journal of Animal Science, v.73, n.11, p.3199-3205, 1995.

UNIVERSIDADE DE CAMPINAS - UNICAMP. Centro de Pesquisas Meteorológicas e Climáticas Aplicadas a Agricultura - CEPAGRI Meteorologia. Available at: <http:// www.cpa.unicamp.br/outras-informacoes/clima-dos-municipiospaulistas.html>. Accessed on: Mar. 30, 2011.
VALADARES FILHO, S.C.; MAGALHÃES, K.A.; ROCHA JÚNIOR, V.R. et al. Tabelas brasileiras de composição de alimentos para bovinos. 2.ed. Viçosa, MG: Universidade Federal de Viçosa, 2006. 329p.

VERDADE, F.C.; HUNGRIA, L.S.; RUSSO, R. et al. Solos da Bacia de Taubaté (Vale do Paraíba). Bragantia, v.20, n.4, p.1-322, 1961. 